\title{
The Assimilation Mechanism of Mn-Al Compacts in Liquid Mg
}

\author{
Zhi $\mathrm{Li}^{* 1}$ and Stavros A. Argyropoulos*2 \\ Department of Materials Science and Engineering, University of Toronto, \\ 184 College Street, Toronto, Ontario M5S 3E4, Canada
}

This paper describes the assimilation mechanism of Mn-Al compacts in liquid $\mathrm{Mg}$, utilizing procedures that have been employed successfully in studying assimilation mechanisms in other liquid metals. Two critical steps were identified in the assimilation process: (1) melting of some $\mathrm{Mn}-\mathrm{Al}$ reaction products and (2) mass transfer of phases with the high $\mathrm{Mn}$ content from the reaction sites into the $\mathrm{Mg}$ bath. The assimilation process was divided into three stages: incubation stage, intermetallic reaction stage, and homogenization stage. Compact swelling was observed during the intermetallic reaction stage. Yet, contrary to the currently-held prevalent view, it was determined that compact swelling was not due primarily to the formation of new intermetallic phases. Rather, swelling is due to the existence of a large amount of porosity initially in the compact which becomes greatly augmented with the large heat released during the Mn-Al exothermic intermetallic reactions. [doi:10.2320/matertrans.M2010063]

(Received February 22, 2010; Accepted May 11, 2010; Published July 25, 2010)

Keywords: assimilation, dissolution, melting, intermetallics, exothermic heat, liquid magnesium, compact swelling, scanning electron microscopy, energy dispersive X-ray spectroscopy

\section{Introduction}

The assimilation process of metallic additions in liquid metals can be divided into two types. The first type, designated as melting, is applicable to additions which have a melting range below the liquid metal temperature. Such additions are said to follow the "melting route". The second type of assimilation can be termed "dissolution", and is pertinent to additions which have a melting range above the liquid metal temperature. These additions are said to pursue the "dissolution route". The usefulness of this classification of assimilation routes as melting or dissolution has been demonstrated in other liquid metals such as steel ${ }^{1)}$ and $\mathrm{Al}^{2)}$ In general, the "melting route" is much faster than the "dissolution route". 1,2)

Mn-Al compact additions have been a common and popular alloying practice in the aluminum industry. ${ }^{3-6)}$ This practice takes advantage of the $\mathrm{Mn}-\mathrm{Al}$ exothermic reactions, which are triggered during the course of assimilation. When these additions are used in $\mathrm{Al}$ processing, they exhibit not only a high $\mathrm{Mn}$ assimilation rate but also consistently high recoveries. Many investigations ${ }^{4-14)}$ have contributed to our understanding of the assimilation process of $\mathrm{Mn}-\mathrm{Al}$ powder compacts in liquid Al.

However, very little research work has been conducted in the assimilation of $\mathrm{Mn}-\mathrm{Al}$ compacts in liquid $\mathrm{Mg}$, at least partially due to the difficulties in working with liquid $\mathrm{Mg}$. Over the past several years, the present authors have begun to examine exothermicity and recovery issues with respect to the assimilation of $\mathrm{Mn}-\mathrm{Al}$ compacts in liquid Mg. ${ }^{15-17)}$ The present work expands on this body of knowledge, and advances our understanding about the assimilation mechanism that is involved with $\mathrm{Mn}-\mathrm{Al}$ compacts in liquid $\mathrm{Mg}$.

\footnotetext{
${ }^{* 1}$ Formerly Graduate Student, Present Postdoctoral Fellow, University of Toronto

${ }^{* 2}$ Corresponding author, E-mail: stavros.argyropoulos@utoronto.ca
}

Table 1 Size distributions of $\mathrm{Al}$ and $\mathrm{Mn}$ powders (Tyler standard sieve series).

\begin{tabular}{cccc}
\hline $\begin{array}{c}\text { Particle Size } \\
(\mu \mathrm{m})\end{array}$ & $\begin{array}{c}\text { Mesh Designation } \\
\text { No. }\end{array}$ & \multicolumn{2}{c}{ Percentage by Mass } \\
\cline { 3 - 4 }$>600$ & +28 & Al Powder & Mn Powder \\
\hline$\leq 600>300$ & $-28+48$ & 3.9 & 0.0 \\
\hline$\leq 300>212$ & $-48+65$ & 12.4 & 9.7 \\
\hline$\leq 212>150$ & $-65+100$ & 38.0 & 22.1 \\
\hline$\leq 150>105$ & $-100+140$ & 39.2 & 26.2 \\
\hline$\leq 105>75$ & $-140+200$ & 5.3 & 22.3 \\
\hline$\leq 75>53$ & $-200+270$ & 0.1 & 14.0 \\
\hline$\leq 53>45$ & $-270+325$ & 0.4 & 0.8 \\
\hline$\leq 45$ & -325 & 0.6 & 3.2 \\
\hline
\end{tabular}

\section{Experimental Work}

Cylindrical compact specimens were manufactured with two-plunger dies under $275 \mathrm{MPa}$ and 5-minute pressure holding time. The screen analysis of the metal powders is listed in Table 1. Two sizes of compact were made: the small compact $(\Phi 19.05 \mathrm{~mm} \times 75 \mathrm{~mm})$ and the large compact $(\Phi 38.1 \mathrm{~mm} \times 75 \mathrm{~mm})$. This was deemed important in order to get a more thorough understanding of the swelling that will take place. In addition, different $\mathrm{Mn}-\mathrm{Al}$ compositions were used in the compact specimens, to study the impact (if any) of various compositions. Figure 1 illustrates the schematics for the small and large diameter compacts. A hole, $2.4 \mathrm{~mm}$ in diameter and $50 \mathrm{~mm}$ in length, was drilled along the compact centerline. At the bottom of this centerline hole, a K-type sheathed thermocouple was inserted to monitor the temperature history of the compact centerline during the immersion tests. The detailed information on the procedures for manufacturing the compacts is reported in references. ${ }^{15,16)}$

Two sets of experiments were conducted. The first set involved immersion of $\mathrm{Mn}-\mathrm{Al}$ compacts into liquid $\mathrm{Mg}$. The 

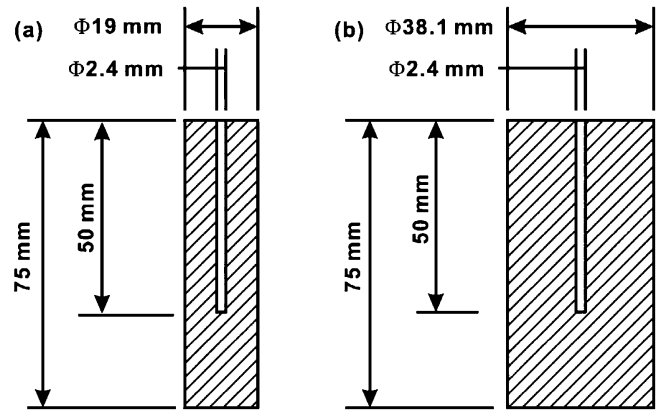

Fig. 1 Schematic of the manufactured small and large cylindrical compacts.

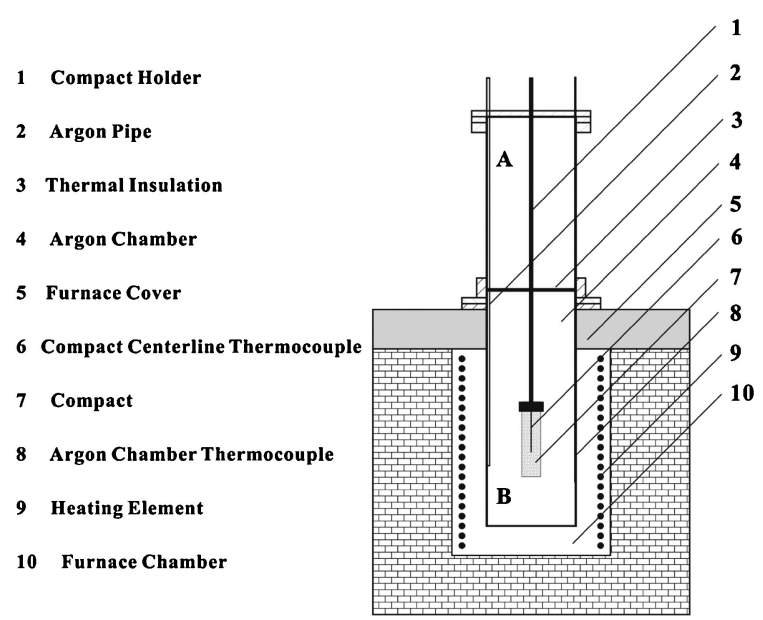

Fig. 2 Schematic of furnace used to heat the specimens under inert $\mathrm{Ar}$ atmosphere.

experimental set-up and operation procedure have been reported in detail elsewhere. ${ }^{15)}$ First, 30 mass $\% \mathrm{Mn} 70$ mass $\% \mathrm{Al}$ compacts were immersed into $750^{\circ} \mathrm{C}$ liquid $\mathrm{Mg}$ for a short period of time (i.e. $30 \mathrm{~s}$ ) and then withdrawn from the Mg bath. Scanning Electron Microscopy (SEM) and Energy Dispersive X-ray Spectroscopy (EDX) analyses were carried out on part of each compact to identify the phases formed during the early stages of $\mathrm{Mn}-\mathrm{Al}$ intermetallic reactions in the compact. Subsequently, the identical process was repeated, allowing the compacts to remain in the $\mathrm{Mg}$ bath for $120 \mathrm{~s}$. These latter experiments were conducted to infer the assimilation mechanism of $\mathrm{Mn}-\mathrm{Al}$ compacts in liquid $\mathrm{Mg}$.

The second set of experiments involved inert heating (i.e. argon) of $\mathrm{Mn}-\mathrm{Al}$ compacts, with different $\mathrm{Mn}-\mathrm{Al}$ compositions. These experiments were designed to determine the final $\mathrm{Mn}-\mathrm{Al}$ intermetallic reaction products in the compact without involvement of the external liquid $\mathrm{Mg}$. Figure 2 depicts schematically the furnace used for this second set of experiments. The furnace utilized two chambers, in which Ar was flushed. The cylindrical compact was heated in the lower chamber, Chamber B. Following this, small samples were taken to perform SEM and EDX analyses. In addition, this set of experiments was also used to measure the volume of the compacts after the exothermic intermetallic reactions had taken place, coinciding with compact swelling. It was important to determine the volume of the portion of the compact that underwent swelling. Given that the swelling
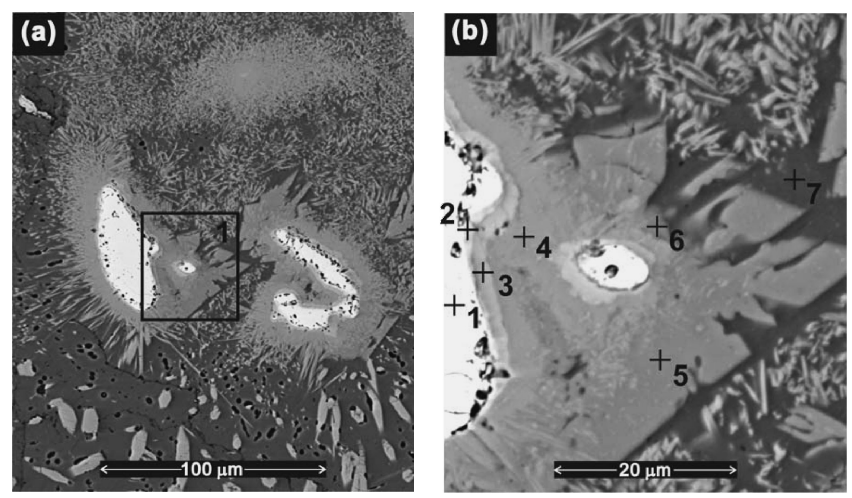

Fig. 3 Backscattered electron image of a section close to the center of a 30 mass $\% \mathrm{Mn} 70$ mass $\% \mathrm{Al}$ compact after a $30 \mathrm{~s}$ immersion into $750^{\circ} \mathrm{C} \mathrm{Mg}$ bath.

Table 2 Results of energy dispersive X-ray analysis at points shown in Fig. 3(b).

\begin{tabular}{|c|c|c|c|c|c|c|}
\hline \multirow{3}{*}{ Point } & \multicolumn{4}{|c|}{ Composition } & \multirow{3}{*}{ Phase } & \multirow{3}{*}{$\begin{array}{l}\text { Equilibrium } \\
\text { Composition } \\
\text { (atom\% Mn) }\end{array}$} \\
\hline & \multicolumn{2}{|c|}{ mass \% } & \multicolumn{2}{|c|}{ atom $\%$} & & \\
\hline & $\mathrm{Al}$ & Mn & $\mathrm{Al}$ & $\mathrm{Mn}$ & & \\
\hline 1 & 1.05 & 98.95 & 2.12 & 97.88 & $\alpha \mathrm{Mn}$ & $91-100$ \\
\hline 2 & 6.07 & 93.93 & 11.63 & 88.37 & $\beta \mathrm{Mn}$ & $59-100$ \\
\hline 3 & 45.75 & 54.26 & 63.19 & 36.81 & $\mathrm{Al}_{8} \mathrm{Mn}_{5}$ & $32.4-51.1$ \\
\hline 4 & 52.29 & 47.71 & 69.05 & 30.95 & $\mathrm{Al}_{11} \mathrm{Mn}_{4}$ & 26.6 \\
\hline 5 & 65.79 & 34.22 & 79.65 & 20.35 & $\mathrm{Al}_{4} \mathrm{Mn}$ & 20 \\
\hline 6 & 74.79 & 25.22 & 85.79 & 14.21 & $\mathrm{Al}_{6} \mathrm{Mn}$ & 14.3 \\
\hline 7 & 96.23 & 3.78 & 98.11 & 1.89 & $\mathrm{Al}$ & $0-0.7$ \\
\hline
\end{tabular}

is not perfectly uniform, the volume was estimated in a piecemeal manner. Specifically, the portion of the specimen that underwent swelling was divided into smaller portions with uniform swelling, and the volume of each of these portions was estimated. The sum of these portions constituted the compact's estimated volume.

\section{Results and Discussion}

\subsection{Assimilation mechanism of Mn-Al compacts in liquid $\mathrm{Mg}$}

Figure 3(a) shows the backscatter electron image of a section close to the center of a 30 mass $\% \mathrm{Mn} 70$ mass $\% \mathrm{Al}$ compact after a $30 \mathrm{~s}$ immersion into $750^{\circ} \mathrm{C} \mathrm{Mg}$ bath. Figure 3(b) shows the magnification of area 1 of Fig. 3. The corresponding results of energy dispersive X-ray analysis are listed in Table 2. The microstructures shown in Fig. 3 are prevalent in the entire sample section. Although considerable primary $\mathrm{Mn}$ is apparent, the development of intermetallic compounds is illustrated. This fact indicates that the intermetallic reactions have already been initiated, which led to the formation of $\mathrm{Mn}-\mathrm{Al}$ intermetallic compounds around the Mn particles. The free aluminum can still be found at this time. It is worthwhile to note that the phase compositions shown in Table 2 deviated from the equilibrium counterparts, i.e., these phases were in a non-stoichiometric range compared to the equilibrium compositions. From these results, it can be deduced that the intermetallic reactions that 
occurred in the Mn-Al powder compact proceeded in a stepwise manner during the immersion test. The reaction products include almost all phases which exist in the binary $\mathrm{Mn}-\mathrm{Al}$ phase diagram from $\alpha \mathrm{Mn}$ (low $\mathrm{Al}$ content) to $\mathrm{Al}_{6} \mathrm{Mn}$ (high $\mathrm{Al}$ content). With respect to the reaction sequence, three steps are exhibited.

Step 1: As long as the liquefied Al from the compact comes in contact with the Mn particle in the Mn-Al compact, the following two reactions are initiated.

$$
\begin{aligned}
& \text { (Al side) } \mathrm{Mn}+\mathrm{Al} \rightarrow \text { Liquid solution of } \mathrm{Mn} \text { in } \mathrm{Al} \\
& \text { (Mn side) } \mathrm{Mn}+\mathrm{Al} \rightarrow \alpha \mathrm{Mn}
\end{aligned}
$$

The first reaction products at the interface of pure solid Mn and pure liquid $\mathrm{Al}$ are expected to be a liquid solution of $\mathrm{Mn}$ in $\mathrm{Al}$ at the $\mathrm{Al}$ side, and $\alpha \mathrm{Mn}$ at the $\mathrm{Mn}$ side. Figure 3(b) indicates that the phases are $\alpha \mathrm{Mn}, \beta \mathrm{Mn}, \mathrm{Al}_{8} \mathrm{Mn}_{5}, \mathrm{Al}_{11} \mathrm{Mn}_{4}$, $\mathrm{Al}_{4} \mathrm{Mn}, \mathrm{Al}_{6} \mathrm{Mn}$, and $\mathrm{Al}$ as one moves from the $\mathrm{Mn}$ rich side to the Al rich side.

Step 2: Along with the diffusion of $\mathrm{Mn}$ and $\mathrm{Al}$ atoms across the intermetallic layers toward the liquid $\mathrm{Al}$ and solid $\mathrm{Mn}$, the following intermetallic reactions may have taken place in succession.

$$
\begin{aligned}
& \left(\mathrm{Al} \text { side) } \mathrm{Al}+\mathrm{Mn} \rightarrow \mathrm{Al}_{6} \mathrm{Mn}\right. \\
& (\mathrm{Mn} \text { side) } \alpha \mathrm{Mn}+\mathrm{Al} \rightarrow \beta \mathrm{Mn} \\
& \left(\mathrm{Al} \text { side) } \mathrm{Al}_{6} \mathrm{Mn}+\mathrm{Mn} \rightarrow \mathrm{Al}_{4} \mathrm{Mn}\right. \\
& \left(\mathrm{Mn} \text { side) } \beta \mathrm{Mn}+\mathrm{Al} \rightarrow \mathrm{Al}_{8} \mathrm{Mn}_{5}\right. \\
& \left(\mathrm{Al} \text { side) } \mathrm{Al}_{4} \mathrm{Mn}+\mathrm{Mn} \rightarrow \mathrm{Al}_{11} \mathrm{Mn}_{4}\right. \\
& \left(\mathrm{Mn} \text { side) } \mathrm{Al}_{8} \mathrm{Mn}_{5}+\mathrm{Al} \rightarrow \mathrm{Al}_{11} \mathrm{Mn}_{4}\right.
\end{aligned}
$$

So, a full series of $\mathrm{Mn}$-Al phases, $\alpha \mathrm{Mn}, \beta \mathrm{Mn}, \mathrm{Al}_{8} \mathrm{Mn}_{5}$, $\mathrm{Al}_{11} \mathrm{Mn}_{4}, \mathrm{Al}_{4} \mathrm{Mn}, \mathrm{Al}_{6} \mathrm{Mn}$ and $\mathrm{Al}$, exist between the $\mathrm{Mn}$ particle and liquid Al. This situation can be seen in Fig. 3(b). Step 3: After step 2, further intermetallic reactions depend upon specific reaction circumstances. Under the condition of $\mathrm{Al}$ deficiency, the intermetallic phases will be formed according to the following reactions. In such a case, the final reaction products will be the phases with a high $\mathrm{Mn}$ content.

$$
\begin{aligned}
& \mathrm{Al}+\mathrm{Mn} \rightarrow \mathrm{Al}_{6} \mathrm{Mn} \\
& \mathrm{Al}_{6} \mathrm{Mn}+\mathrm{Mn} \rightarrow \mathrm{Al}_{4} \mathrm{Mn} \\
& \mathrm{Al}_{4} \mathrm{Mn}+\mathrm{Mn} \rightarrow \mathrm{Al}_{11} \mathrm{Mn}_{4} \\
& \mathrm{Al}_{11} \mathrm{Mn}_{4}+\mathrm{Mn} \rightarrow \mathrm{Al}_{8} \mathrm{Mn}_{5} \\
& \mathrm{Al}_{8} \mathrm{Mn}_{5}+\mathrm{Mn} \rightarrow \beta \mathrm{Mn} \\
& \beta \mathrm{Mn}+\mathrm{Mn} \rightarrow \alpha \mathrm{Mn}
\end{aligned}
$$

Correspondingly, Equations (4) describe the intermetallic reactions procedure under the condition of Al surplus. In such a case, the final reaction products will be the liquid solution of $\mathrm{Mn}$ in Al. All the Mn can be assimilated.

$$
\begin{aligned}
& \alpha \mathrm{Mn}+\mathrm{Al} \rightarrow \beta \mathrm{Mn} \\
& \beta \mathrm{Mn}+\mathrm{Al} \rightarrow \mathrm{Al}_{8} \mathrm{Mn}_{5} \\
& \mathrm{Al}_{8} \mathrm{Mn}_{5}+\mathrm{Al} \rightarrow \mathrm{Al}_{11} \mathrm{Mn}_{4} \\
& \mathrm{Al}_{11} \mathrm{Mn}_{4}+\mathrm{Al} \rightarrow \mathrm{Al}_{4} \mathrm{Mn} \\
& \mathrm{Al}_{4} \mathrm{Mn}+\mathrm{Al} \rightarrow \mathrm{Al}_{6} \mathrm{Mn} \\
& \mathrm{Al}_{6} \mathrm{Mn}+\mathrm{Al} \rightarrow \text { Liquid Solution of } \mathrm{Mn} \text { in } \mathrm{Al}
\end{aligned}
$$

Figures 4 to 6 demonstrate the typical backscattered electron images $\mathrm{Mn}-\mathrm{Al}$ powder compacts of different

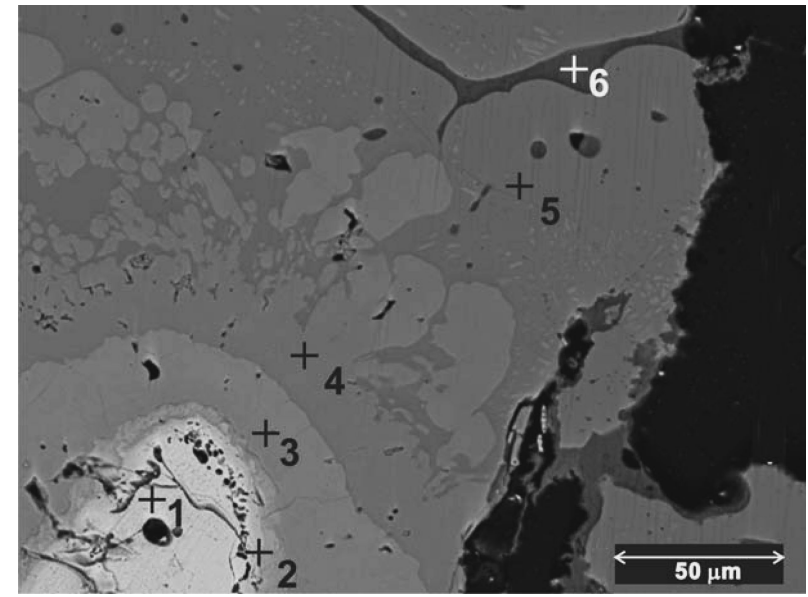

Fig. 4 Backscattered electron image of a typical section of a 30 mass $\% \mathrm{Mn} 70$ mass\% $\mathrm{Al}$ compact immersed in $750^{\circ} \mathrm{C}$ argon protective atmosphere.

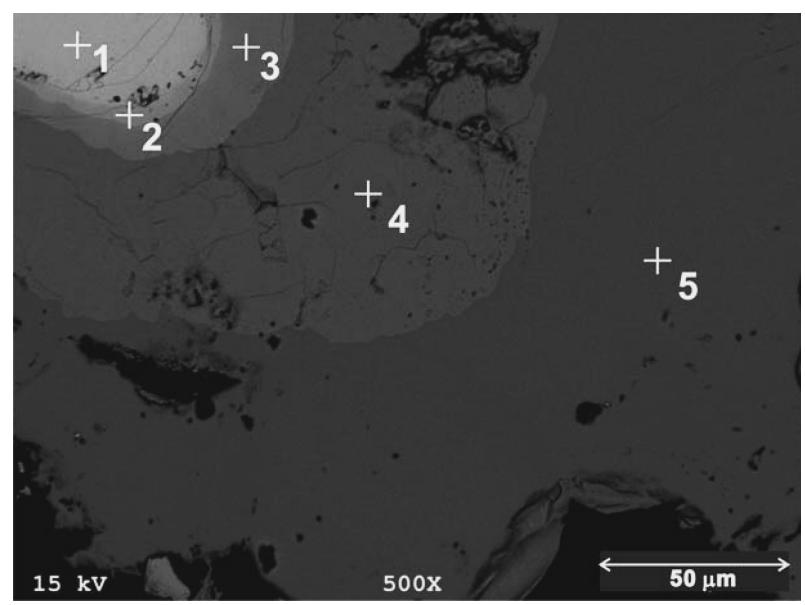

Fig. 5 Backscattered electron image of a typical section of a 40 mass $\% \mathrm{Mn} 60$ mass $\% \mathrm{Al}$ compact immersed in $750^{\circ} \mathrm{C}$ argon protective atmosphere.

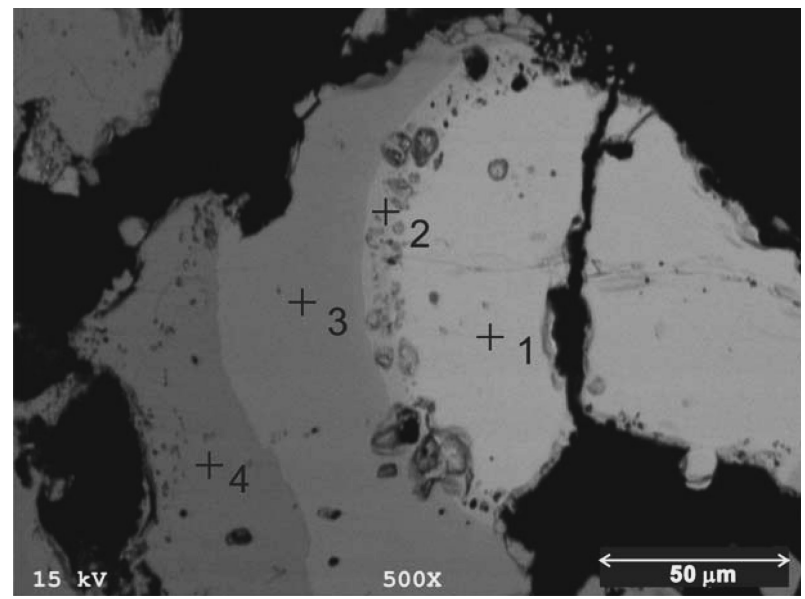

Fig. 6 Backscattered electron image of a typical section of a 50 mass $\% \mathrm{Mn} 50$ mass $\% \mathrm{Al}$ compact immersed in $750^{\circ} \mathrm{C}$ argon protective atmosphere.

compositions heated in a $750^{\circ} \mathrm{C}$ argon protective atmosphere. The corresponding energy dispersive X-ray analysis data are listed in Tables 3 to 5 . It should be pointed out that the 
Table 3 Results of energy dispersive X-ray analysis at points shown in Fig. 4.

\begin{tabular}{|c|c|c|c|c|c|c|}
\hline \multirow{3}{*}{ Point } & \multicolumn{4}{|c|}{ Composition } & \multirow{3}{*}{ Phase } & \multirow{3}{*}{$\begin{array}{l}\text { Equilibrium } \\
\text { Composition } \\
\text { (atom\% Mn) }\end{array}$} \\
\hline & \multicolumn{2}{|c|}{$\operatorname{mass} \%$} & \multicolumn{2}{|c|}{ atom $\%$} & & \\
\hline & $\mathrm{Al}$ & $\mathrm{Mn}$ & $\mathrm{Al}$ & $\mathrm{Mn}$ & & \\
\hline 1 & 4.26 & 95.75 & 8.30 & 91.70 & $\alpha \mathrm{Mn}$ & $91-100$ \\
\hline 2 & 17.25 & 82.75 & 29.80 & 70.20 & $\beta \mathrm{Mn}$ & 59-100 \\
\hline 3 & 38.97 & 61.03 & 56.53 & 43.47 & $\mathrm{Al}_{8} \mathrm{Mn}_{5}$ & $32.4-51.1$ \\
\hline 4 & 53.80 & 46.20 & 70.34 & 29.66 & $\mathrm{Al}_{11} \mathrm{Mn}_{4}$ & 26.6 \\
\hline 5 & 63.71 & 36.30 & 78.14 & 21.86 & $\mathrm{Al}_{4} \mathrm{Mn}$ & 20 \\
\hline 6 & 75.18 & 24.83 & 86.04 & 13.96 & $\mathrm{Al}_{6} \mathrm{Mn}$ & 14.3 \\
\hline
\end{tabular}

Table 4 Results of energy dispersive X-ray analysis at points shown in Fig. 5.

\begin{tabular}{|c|c|c|c|c|c|c|}
\hline \multirow{3}{*}{ Point } & \multicolumn{4}{|c|}{ Composition } & \multirow{3}{*}{ Phase } & \multirow{3}{*}{$\begin{array}{l}\text { Equilibrium } \\
\text { Composition } \\
\text { (atom\% Mn) }\end{array}$} \\
\hline & \multicolumn{2}{|c|}{ mass $\%$} & \multicolumn{2}{|c|}{ atom $\%$} & & \\
\hline & $\mathrm{Al}$ & $\mathrm{Mn}$ & $\mathrm{Al}$ & $\mathrm{Mn}$ & & \\
\hline 1 & 4.7 & 95.3 & 9.2 & 90.8 & $\alpha \mathrm{Mn}$ & 91-100 \\
\hline 2 & 20.8 & 79.2 & 34.9 & 65.1 & $\beta \mathrm{Mn}$ & $59-100$ \\
\hline 3 & 40.7 & 59.3 & 58.3 & 41.7 & $\mathrm{Al}_{8} \mathrm{Mn}_{5}$ & $32.4-51.1$ \\
\hline 4 & 53.5 & 46.5 & 70.1 & 29.9 & $\mathrm{Al}_{11} \mathrm{Mn}_{4}$ & 26.6 \\
\hline 5 & 61.4 & 38.6 & 76.4 & 23.6 & $\mathrm{Al}_{4} \mathrm{Mn}$ & 20 \\
\hline
\end{tabular}

Table 5 Results of energy dispersive X-ray analysis at points shown in Fig. 6.

\begin{tabular}{|c|c|c|c|c|c|c|}
\hline \multirow{3}{*}{ Point } & \multicolumn{4}{|c|}{ Composition } & \multirow{3}{*}{ Phase } & \multirow{3}{*}{$\begin{array}{l}\text { Equilibrium } \\
\text { Composition } \\
\text { (atom\% Mn) }\end{array}$} \\
\hline & \multicolumn{2}{|c|}{ mass $\%$} & \multicolumn{2}{|c|}{ atom $\%$} & & \\
\hline & $\mathrm{Al}$ & $\mathrm{Mn}$ & $\mathrm{Al}$ & $\mathrm{Mn}$ & & \\
\hline 1 & 2.6 & 97.4 & 5.1 & 94.9 & $\alpha \mathrm{Mn}$ & $91-100$ \\
\hline 2 & 20.6 & 79.4 & 34.6 & 65.4 & $\beta \mathrm{Mn}$ & 59-100 \\
\hline 3 & 40.7 & 59.3 & 58.2 & 41.8 & $\mathrm{Al}_{8} \mathrm{Mn}_{5}$ & $32.4-51.1$ \\
\hline 4 & 53.0 & 47.0 & 69.7 & 30.3 & $\mathrm{Al}_{11} \mathrm{Mn}_{4}$ & 26.6 \\
\hline
\end{tabular}

post-reacted compacts were cooled down to ambient temperature under the argon protection, and the phases witnessed in the compacts are the final reaction products. Again, from these backscattered electron images, some primary $\mathrm{Mn}$ particles can be seen, and a series of $\mathrm{Mn}-\mathrm{Al}$ intermetallic compound layers encase the Mn particle cores. These phenomena indicate that the intermetallic reactions occurring under such conditions are not complete reactions. Therefore, the initial atomic ratio of $\mathrm{Al}$ to $\mathrm{Mn}$ in the compact is not responsible for the final reaction products.

Table 6 tabulates the atomic ratio of $\mathrm{Al}$ to $\mathrm{Mn}$ in various $\mathrm{Mn}-\mathrm{Al}$ compact compositions. As can be seen, the maximum atomic ratio is 4.75 , in the case of a 30 mass $\% \mathrm{Mn} 70$ mass $\% \mathrm{Al}$ compact. This means that the intermetallic reactions in the compacts studied proceeded under the condition of $\mathrm{Al}$ deficiency even in the relatively Al-rich 30 mass $\% \mathrm{Mn} 70$ mass\%Al compact. Therefore, the final reaction products might be a small or large part of the reaction products that appeared in Equations (3) depending upon the amount of $\mathrm{Al}$ in the compact. The energy dispersive
Table 6 Atomic ratio of $\mathrm{Al}$ to $\mathrm{Mn}$ for various $\mathrm{Mn}-\mathrm{Al}$ compacts.

\begin{tabular}{|c|c|c|c|c|c|}
\hline \multirow{3}{*}{ Compact Type } & \multicolumn{4}{|c|}{ Composition } & \multirow{3}{*}{$\begin{array}{c}\text { Atomic Ratio } \\
\text { (Al:Mn) }\end{array}$} \\
\hline & \multicolumn{2}{|c|}{$\operatorname{mass} \%$} & \multicolumn{2}{|c|}{ atom $\%$} & \\
\hline & $\mathrm{Al}$ & $\mathrm{Mn}$ & $\mathrm{Al}$ & $\mathrm{Mn}$ & \\
\hline 75 mass $\% \mathrm{Mn} 25$ mass $\% \mathrm{Al}$ & 25 & 75 & 0.40 & 0.60 & 0.68 \\
\hline 60 mass $\% \mathrm{Mn} 40$ mass $\% \mathrm{Al}$ & 40 & 60 & 0.58 & 0.42 & 1.36 \\
\hline 50 mass $\% \mathrm{Mn} 50$ mass $\% \mathrm{Al}$ & 50 & 50 & 0.67 & 0.33 & 2.04 \\
\hline 40 mass $\%$ Mn60 mass $\% \mathrm{Al}$ & 60 & 40 & 0.75 & 0.25 & 3.05 \\
\hline 30 mass $\% \mathrm{Mn} 70$ mass $\% \mathrm{Al}$ & 70 & 30 & 0.83 & 0.17 & 4.75 \\
\hline
\end{tabular}

$\mathrm{X}$-ray analysis confirmed our judgment. From Tables 3 to 5, when the $\mathrm{Mn}-\mathrm{Al}$ powder compacts were heated in a $750^{\circ} \mathrm{C}$ argon protective environment, the final reaction products for a 30 mass $\% \mathrm{Mn} 70$ mass $\% \mathrm{Al}$ compact included $\alpha \mathrm{Mn}, \beta \mathrm{Mn}$, $\mathrm{Al}_{8} \mathrm{Mn}_{5}, \mathrm{Al}_{11} \mathrm{Mn}_{4}, \mathrm{Al}_{4} \mathrm{Mn}$, and $\mathrm{Al}_{6} \mathrm{Mn}$ since there is a relatively large $\mathrm{Al}$ content in a 30 mass $\% \mathrm{Mn} 70$ mass\% $\mathrm{Al}$ compact, which can be seen in Fig. 4 and Table 3. When the $\mathrm{Al}$ composition in a $\mathrm{Mn}-\mathrm{Al}$ compact is reduced, such as in the case of a 40 mass $\% \mathrm{Mn} 60$ mass $\% \mathrm{Al}$, the final reaction products are $\alpha \mathrm{Mn}, \beta \mathrm{Mn}, \mathrm{Al}_{8} \mathrm{Mn}_{5}, \mathrm{Al}_{11} \mathrm{Mn}_{4}$, and $\mathrm{Al}_{4} \mathrm{Mn}$ without $\mathrm{Al}_{6} \mathrm{Mn}$, thus can be seen in Fig. 5 and Table 4. With a further decrease in $\mathrm{Al}$ composition in the compact, the final reaction products are composed only of the high Mn phases such as $\alpha \mathrm{Mn}, \beta \mathrm{Mn}, \mathrm{Al}_{8} \mathrm{Mn}_{5}$ and $\mathrm{Al}_{11} \mathrm{Mn}_{4}$. This is the situation for the 50 mass $\% \mathrm{Mn} 50$ mass $\% \mathrm{Al}$, the 60 mass $\% \mathrm{Mn} 40$ mass $\% \mathrm{Al}$, and the 75 mass $\% \mathrm{Mn} 25$ mass $\% \mathrm{Al}$ compacts. The results for the 50 mass $\% \mathrm{Mn} 50$ mass $\% \mathrm{Al}$ compact can be found in Fig. 6 and Table 5. In a typical $\mathrm{Mg}$ bath temperature of $750^{\circ} \mathrm{C}$, the phase $\mathrm{Al}_{6} \mathrm{Mn}\left(704.85^{\circ} \mathrm{C}\right)$ and $\mathrm{Al}$ solution are liquid. As such, they certainly can be assimilated into liquid $\mathrm{Mg}$ rapidly. On the other hand, the reaction products such as $\mathrm{Al}_{11} \mathrm{Mn}_{4}\left(989.25^{\circ} \mathrm{C}\right)$ and $\mathrm{Al}_{4} \mathrm{Mn}$, $\left(919.95^{\circ} \mathrm{C}\right)$ have lower melting points compared to elemental $\mathrm{Mn}$. Taking the reaction heat released from the $\mathrm{Mn}-\mathrm{Al}$ exothermic reactions into account, the intermetallic compounds $\mathrm{Al}_{11} \mathrm{Mn}_{4}$ and $\mathrm{Al}_{4} \mathrm{Mn}$ also have the potential to be in liquid phase. That means that they might be melted into liquid $\mathrm{Mg}$. Melting part of the $\mathrm{Mn}-\mathrm{Al}$ reaction products becomes a route to assimilate the $\mathrm{Mn}-\mathrm{Al}$ powder compact into the liquid $\mathrm{Mg}$.

Figure 7 shows the temperature history of a 50 mass\% Mn50 mass\%Al small compact immersed in an $\mathrm{Ar}$ protected furnace chamber at $750^{\circ} \mathrm{C}$. Line 1 of Fig. 7 corresponds to the temperature history of the Ar protected furnace chamber. During the time period represented by segment $\mathrm{AB}$ of Line 1, the compact specimen was held in Chamber $A$ of the heating furnace shown in Fig. 2. Upon introducing the compact into Chamber B, a small drop in temperature was recorded, indicated by segment BCD. The heat absorbed by the relatively cool compact specimen is responsible for this small temperature drop. Segment DE indicates some modest heating of Chamber B. This was due to the fact that during this time period, the exothermic intermetallic reactions were triggered and the released heat increased the temperature of the $\mathrm{Ar}$ protected heating chamber. The subsequent segment, EF, of Line 1 indicates a gradual drop of the temperature in the heating chamber. Line 2 of Fig. 7 corresponds to the compact's centerline 
temperature. Segment GH of Line 2 indicates part of the time period the compact specimen was held in the $\mathrm{Ar}$ protected Chamber A, which was not heated. The slight increase in the centerline temperature, $\mathrm{GH}$, was due to the convection and radiation heat transferred to the compact from the heated Chamber B. Upon immersion of the compact into Chamber B, a rapid increase in the centerline temperature was registered, as seen in segment $\mathrm{HI}$ of Line 2. Segment IK corresponds to the melting of the $\mathrm{Al}$ powder in the compact. The subsequent triggering of exothermic intermetallic reactions was responsible for the abrupt increase in the centerline compact temperature, represented

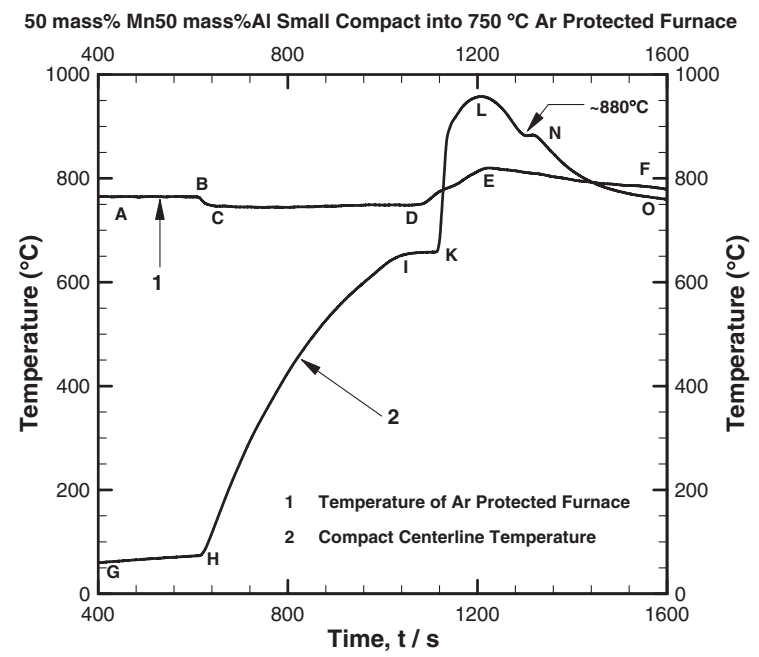

Fig. 7 Temperature plot of a 50 mass $\% \mathrm{Mn} 50$ mass $\% \mathrm{Al}$ compact into a $750^{\circ} \mathrm{C}$ Ar protected furnace. by the segment KL of Line 2. The localized nature of exothermicity involved can be seen from the different maximum temperatures recorded, as indicated by point $\mathrm{E}$ (Line 1) and point $\mathrm{L}$ (Line 2). This difference in the maximum temperatures (points $\mathrm{E}$ and $\mathrm{L}$ ), was approximately $150^{\circ} \mathrm{C}$. It can be seen that during the period of the compact cooling, indicated by segment LMNO, there is a plateau, segment $\mathrm{MN}$, at about $880^{\circ} \mathrm{C}$ of the compact centerline temperature. It is obvious that this plateau corresponds to a liquid-solid phase transformation. This implies that a particular phase within the reaction products was melted by the energy released from the $\mathrm{Mn}-\mathrm{Al}$ exothermic reactions in the compact. Subsequently, this phase solidified, as indicated by segment MN. The phase which is responsible for the liquid-solid transformation plateau shown in Fig. 7 is considered to be $\mathrm{Al}_{4} \mathrm{Mn}$. The difference between the plateau temperature and the melting point of $\mathrm{Al}_{4} \mathrm{Mn}$ might be due to the deviation from the equilibrium phase composition.

Figure 8 displays an entire cross section of a 30 mass $\% \mathrm{Mn} 70$ mass \% Al compact withdrawn from a $750^{\circ} \mathrm{C}$ $\mathrm{Mg}$ bath after $120 \mathrm{~s}$ of immersion. Two types of zones can be distinguished from this figure: a clear zone (outer surface) and blurred zone (center/inner part). Figure 9 shows a typical zone, which crosses the clear zone and the blurred zone. The phase identification was conducted in this zone and the EDX results are listed in Table 7. Area 1 in Fig. 9 is located in the blurred zone, while Area 2 is located in the clear zone. The EDX results for Area 1 (blurred zone) indicate that the intermetallic compound layers still contain $\mathrm{Al}_{4} \mathrm{Mn}$, which has a relatively low melting point. In addition, the $\mathrm{Mg}$ concentrations at the matrix points (points 1-4, 1-5, and 1-6) are relatively low, but $\mathrm{Mn}$ and $\mathrm{Al}$ concentrations are
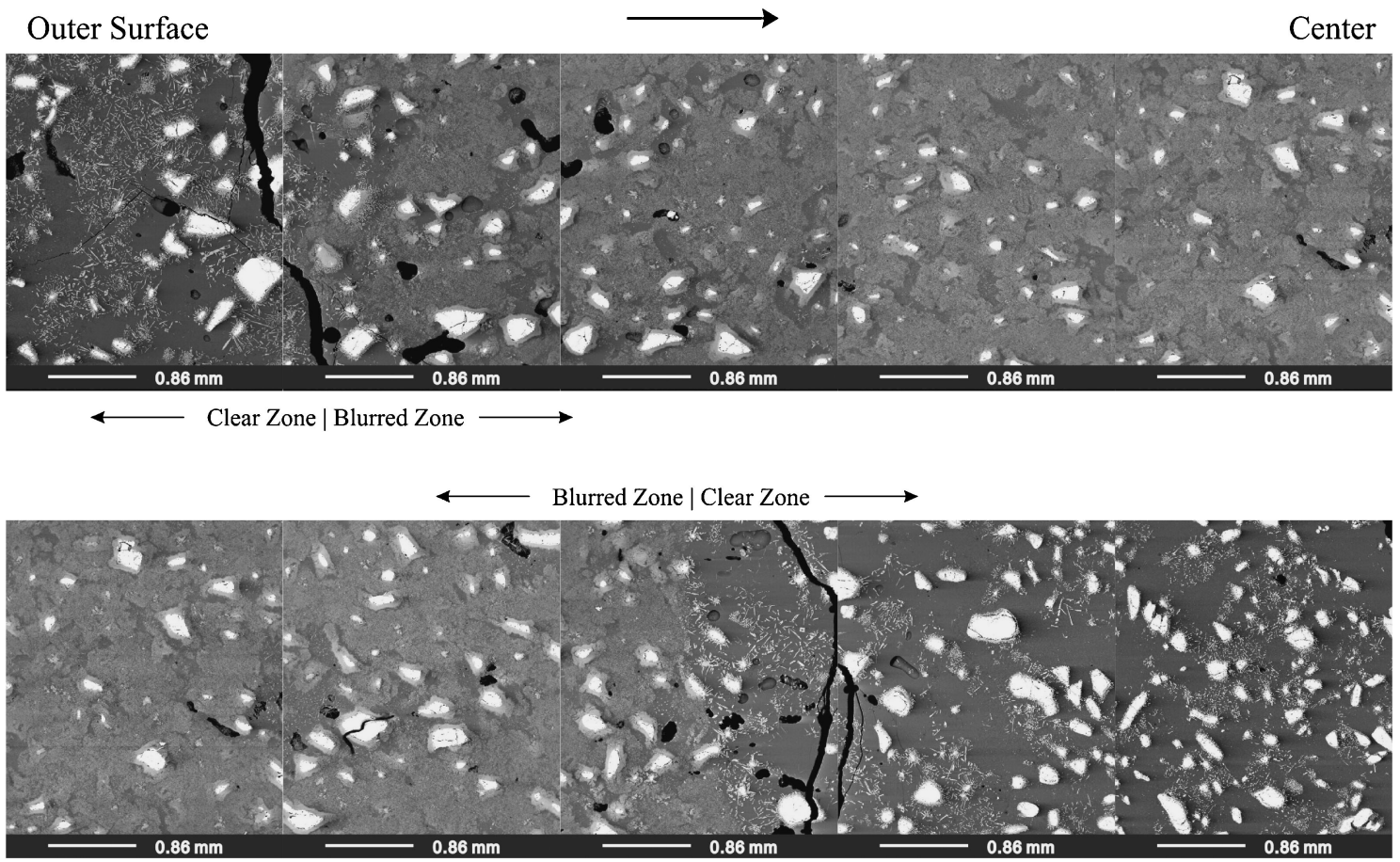

Center

Outer Surface

Fig. 8 Backscattered electron image for a whole cross section of a 30 mass $\% \mathrm{Mn} 70$ mass $\% \mathrm{Al}$ compact withdrawn from a $750{ }^{\circ} \mathrm{C}$ Mg bath after $120 \mathrm{~s}$ of immersion. 


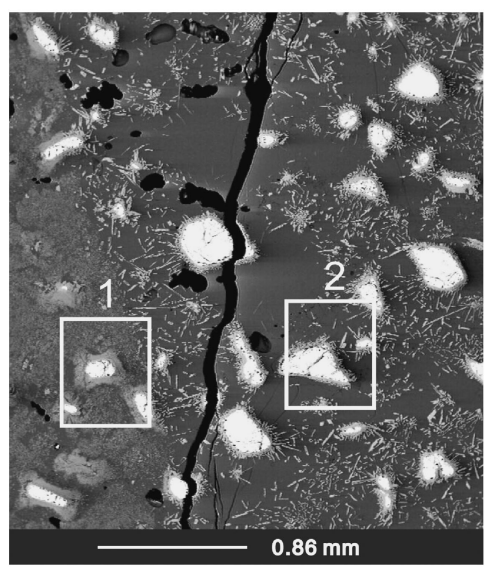

1
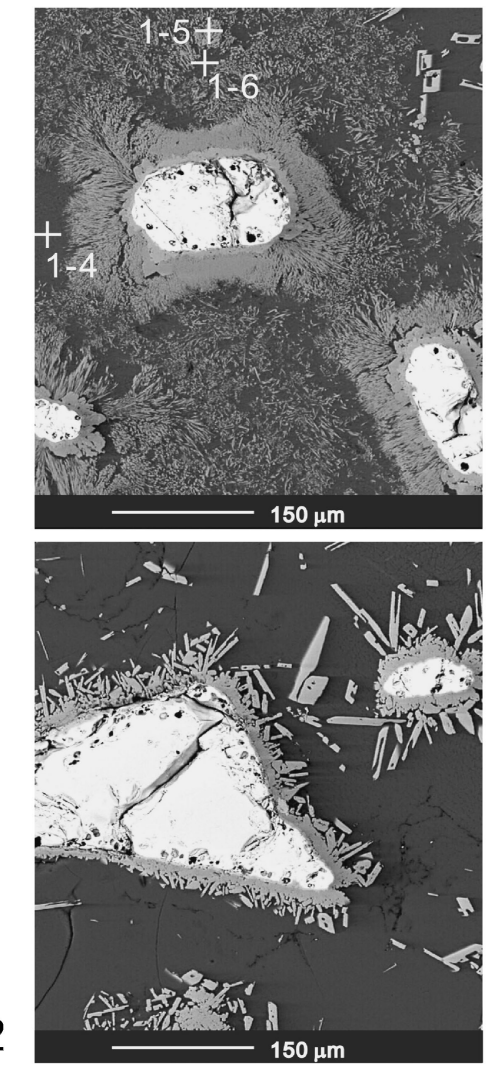
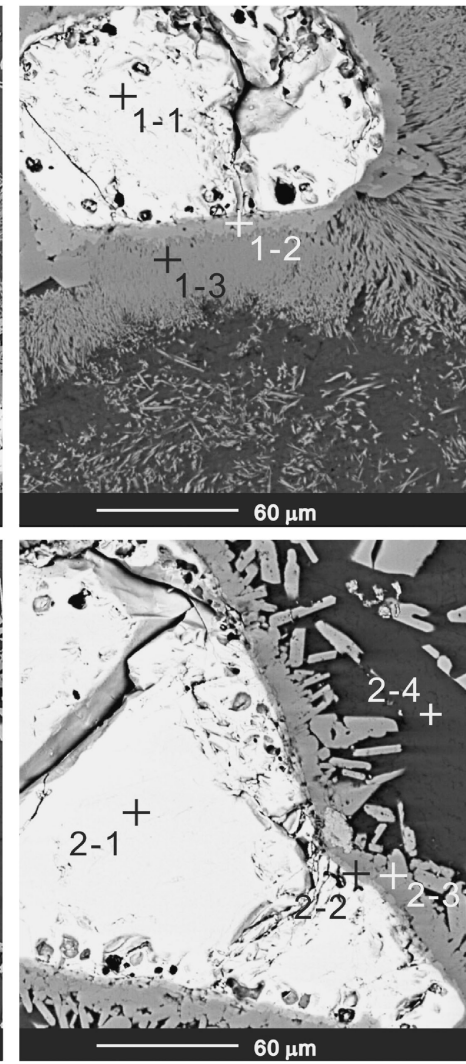

Fig. 9 Magnified Backscattered electron image of a typical area including both blur zone and clear zone in Fig. 8.

Table 7 Results of energy dispersive X-ray analysis at points shown in Fig. 9.

\begin{tabular}{|c|c|c|c|c|c|c|c|}
\hline \multirow{2}{*}{ Point } & \multirow{2}{*}{$\begin{array}{c}\mathrm{Mg} \\
(\mathrm{at} \%)\end{array}$} & \multirow{2}{*}{$\begin{array}{c}\mathrm{Al} \\
(\mathrm{at} \%)\end{array}$} & \multirow{2}{*}{$\begin{array}{c}\mathrm{Mn} \\
(\mathrm{at} \%)\end{array}$} & \multirow{2}{*}{ Phase } & \multicolumn{3}{|c|}{ Equilibrium Composition } \\
\hline & & & & & (at $\% \mathrm{Mn})$ & (at\% $\mathrm{Mg}$ ) & (at\% Al) \\
\hline $1-1$ & 0.7 & 0.7 & 98.6 & $\alpha \mathrm{Mn}$ & $91-100$ & & \\
\hline $1-2$ & 0 & 74.4 & 25.6 & $\mathrm{Al}_{11} \mathrm{Mn}_{4}$ & 26.6 & & \\
\hline $1-3$ & 5.6 & 78.3 & 16.1 & $\mathrm{Al}_{4} \mathrm{Mn}$ & 20 & & \\
\hline $1-4$ & 29.0 & 70.9 & 0.1 & $\mathrm{Al}_{2} \mathrm{Mg}$ & & 33.3 & \\
\hline $1-5$ & 11.5 & 75.6 & 12.9 & $\mathrm{Al}_{18} \mathrm{Mg}_{3} \mathrm{Mn}_{2}$ & 8.7 & 13.0 & 78.3 \\
\hline $1-6$ & 28.2 & 68.0 & 3.8 & $\mathrm{Al}_{2} \mathrm{Mg}$ & & 33.3 & \\
\hline $2-1$ & 0.6 & 0.5 & 98.9 & $\alpha \mathrm{Mn}$ & $91-100$ & & \\
\hline $2-2$ & 0.0 & 66.2 & 33.8 & $\mathrm{Al}_{8} \mathrm{Mn}_{5}$ & $32.4-51.1$ & & \\
\hline $2-3$ & 0.1 & 75.0 & 24.9 & $\mathrm{Al}_{11} \mathrm{Mn}_{4}$ & 26.6 & & \\
\hline $2-4$ & 60.5 & 39.4 & 0.1 & $\mathrm{Al}_{12} \mathrm{Mg}_{17}$ & & $45-60.5$ & \\
\hline
\end{tabular}

relatively high. For Area 2, (clear zone) the Mg concentration at the matrix point (point 2-4) is relatively high, and $\mathrm{Mn}$ and $\mathrm{Al}$ concentrations are relatively low. Furthermore, the relatively low melting point phase $\mathrm{Al}_{4} \mathrm{Mn}$ does not exist. These facts imply that in the clear zone (e.g., Area 2), the $\mathrm{Mn}-\mathrm{Al}$ intermetallic reactions have finished. The low melting point $\mathrm{Al}_{4} \mathrm{Mn}$ has been melted by the reaction heat. The relatively low concentrations of $\mathrm{Mn}$ and $\mathrm{Al}$ in the matrix indicate that the melted $\mathrm{Mn}-\mathrm{Al}$ intermetallic compounds have been thoroughly swept into the liquid $\mathrm{Mg}$ when the liquid $\mathrm{Mg}$ penetrated into the compact and flushed it. On the other hand, in the blurred zone (e.g., Area 1), the low melting point $\mathrm{Al}_{4} \mathrm{Mn}$ still exists. The relatively high concentrations of
$\mathrm{Mn}$ and $\mathrm{Al}$ and relatively low concentrations of $\mathrm{Mg}$ in the matrix indicate that the liquid $\mathrm{Mg}$ has not thoroughly flushed the reaction sites. All these observations suggest that the MnAl intermetallic reactions have not finished in the blurred zone.

\subsection{Compact swelling}

During the immersion of compacts into liquid $\mathrm{Mg}$, when the intermetallic reactions were triggered, compact swelling was observed. ${ }^{15,16)}$ Figure 10 displays a 60 mass $\% \mathrm{Mn} 40$ mass $\% \mathrm{Al}$ compact prior to and post commencement of the exothermic reactions, where the swelling phenomenon is clearly seen. 


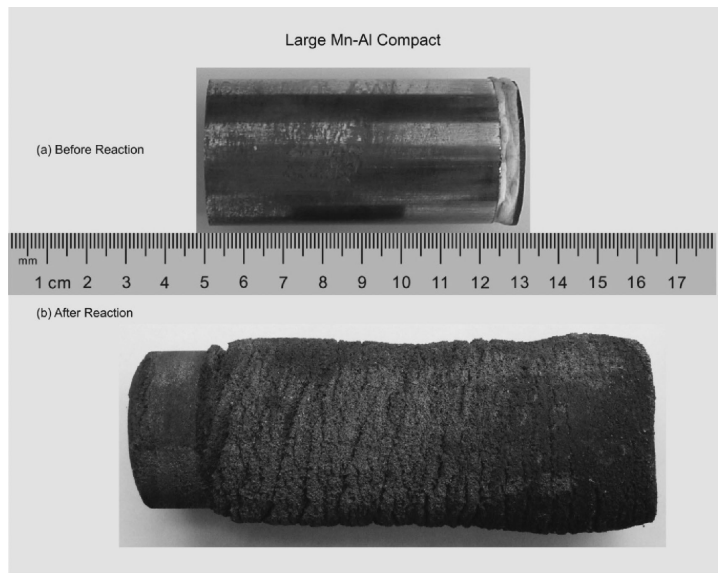

Fig. 10 Swelling phenomenon of a Mn-Al compact after intermetallic reactions in a $750^{\circ} \mathrm{C}$ argon protective environment.

Compact swelling has been reported to take place during assimilation in liquid $\mathrm{Al}$, advancing primarily two different explanations. In the investigation by Perry, ${ }^{7)}$ the initial pretest briquette densities of 75 mass $\% \mathrm{Mn} 25$ mass $\% \mathrm{Al}$ powder compacts were $4.45 \mathrm{~g} / \mathrm{cm}^{3}$ to $4.5 \mathrm{~g} / \mathrm{cm}^{3}$. After removal from the furnace, the densities dropped to an average $2.24 \mathrm{~g} / \mathrm{cm}^{3}$. The observed expansion was attributed to the formation of low density Mn-Al intermetallic compounds and/or the generation of porosity. Shafyei and Guthrie ${ }^{10)}$ also observed swelling of a 75 mass $\% \mathrm{Mn} 25$ mass $\% \mathrm{Al}$ briquette during immersion. The lower density of Mn-Al intermetallic compounds, the Kirkendall effect and the capillary effect were the reasons proposed for the swelling. The low densities of Mn$\mathrm{Al}$ intermetallic compounds were regarded as an important point for the compact swelling in both of these studies.

Only for about half of the intermetallic compounds of the $\mathrm{Mn}-\mathrm{Al}$ system are experimentally-derived density data available in the literature. For the other compounds, their density has been estimated through calculations. Table 8 lists the experimental and calculated data available in the literature for the densities and crystal structures of intermetallic compounds in Al-Mn system. Density values that are underlined were calculated by the present authors from known crystal structure data, according to the following expression: ${ }^{22)}$

$$
\rho=\frac{n_{\mathrm{C}} A}{V_{\mathrm{C}} N_{\mathrm{A}}}
$$

Where

$n_{\mathrm{C}}$ Number of atoms associated with each unit cell;

$A$ Atomic weight;

$V_{\mathrm{C}}$ Volume of the unit cell;

$N_{\mathrm{A}}$ Avogadro's number $\left(6.023 \times 10^{23}\right.$ atoms $\left./ \mathrm{mol}\right)$.

As seen from Table 8, there is good agreement between experimentally determined and calculated intermetallic compound density values.

Table 8 Crystal structures and densities of phases existed in Al-Mg-Mn system.

\begin{tabular}{|c|c|c|c|c|c|c|c|c|c|c|c|c|c|}
\hline \multirow[b]{2}{*}{ Phase } & \multirow{2}{*}{$\begin{array}{l}\text { Crystal } \\
\text { Structure }\end{array}$} & \multirow{2}{*}{$\begin{array}{l}\text { Pearson } \\
\text { Symbol }\end{array}$} & \multicolumn{6}{|c|}{ Lattice Parameter } & \multirow{2}{*}{$\begin{array}{l}\text { Number of } \\
\text { Atoms per } \\
\text { Unit Cell }\end{array}$} & \multirow{2}{*}{$\begin{array}{l}\text { Unit Cell } \\
\text { Volume } \\
\left(\AA^{3}\right)\end{array}$} & \multicolumn{2}{|c|}{ Density $\left(\mathrm{kg} / \mathrm{m}^{3}\right)$} & \multirow[b]{2}{*}{ Ref. } \\
\hline & & & $\begin{array}{c}\mathrm{a} \\
(\AA)\end{array}$ & $\begin{array}{l}\mathrm{b} \\
(\AA)\end{array}$ & $\begin{array}{l}\mathrm{c} \\
(\AA)\end{array}$ & $\begin{array}{l}\alpha \\
\left({ }^{\circ}\right)\end{array}$ & $\begin{array}{l}\beta \\
\left({ }^{\circ}\right)\end{array}$ & $\begin{array}{l}\gamma \\
\left({ }^{\circ}\right)\end{array}$ & & & Experimental & Calculated & \\
\hline $\mathrm{Al}_{97} \mathrm{Mn}_{3}$ & Face-Centered Cubic & $\mathrm{cF} 4$ & 4.0727 & & & & & & 4 & 67.6 & & $\underline{2735}$ & 18) \\
\hline $\mathrm{Al}_{12} \mathrm{Mn}$ & Body-Centered Cubic & cI26 & 7.47 & & & & & & 26 & 416.8 & & $\underline{3017}$ & 18) \\
\hline $\mathrm{Al}_{12} \mathrm{Mn}$ & Cubic & & 13.28 & & & & & & 156 & 2342.0 & & $\underline{3222}$ & 19) \\
\hline $\mathrm{Al}_{9} \mathrm{Mn}$ & Cubic & $\mathrm{cP} 20$ & 6.5190 & & & & & & 20 & 277.0 & & $\underline{3569}$ & 20) \\
\hline $\mathrm{Al}_{6} \mathrm{Mn}$ & $\begin{array}{l}\text { Base-Centered } \\
\text { Orthorhombic }\end{array}$ & oC28 & 7.5518 & 6.4978 & 8.8703 & & & & 28 & 435.3 & 3270 & 3310 & 18) \\
\hline $\mathrm{Al}_{6} \mathrm{Mn}$ & $\begin{array}{l}\text { Base-Centered } \\
\text { Orthorhombic }\end{array}$ & & 6.498 & 7.552 & 8.870 & & & & 28 & 435.3 & & $\underline{3308}$ & 19) \\
\hline $\mathrm{Al}_{57} \mathrm{Mn}_{12}$ & Cubic & $\mathrm{cP} 20$ & 12.680 & & & & & & 138 & 2038.7 & 3580 & $\underline{3578}$ & 20) \\
\hline $\mathrm{Al}_{4} \mathrm{Mn}$ & Simple Orthorhombic & oP60 & 6.795 & 9.343 & 13.897 & & & & 60 & 882.3 & 3650 & $\underline{3678}$ & 18) \\
\hline $\mathrm{Al}_{10} \mathrm{Mn}_{3}$ & Rhombohedral & hP26 & 7.543 & & 7.898 & & & 120 & 26 & 389.2 & 3650 & 3740 & 18) \\
\hline $\mathrm{Al}_{3} \mathrm{Mn}$ & Simple Orthorhombic & oP160 & 14.79 & 12.42 & 12.59 & & & & 160 & 2312.7 & 3905 & $\underline{3902}$ & 18) \\
\hline $\mathrm{Al}_{11} \mathrm{Mn}_{3.85}$ & Triclinic & $\mathrm{aP} 4$ & 5.095 & 8.879 & 5.051 & 89.35 & 100.47 & 105.08 & 14.85 & 220.6 & 3825 & 3825 & 20) \\
\hline $\mathrm{Al}_{11} \mathrm{Mn}_{4}$ & Triclinic & aP15 & 5.092 & 8.862 & 5.047 & 85.32 & 100.4 & 105.33 & 15 & 218.9 & 4100 & $\underline{3917}$ & 18) \\
\hline $\mathrm{Al}_{8} \mathrm{Mn}_{5}$ & Rhombohedral & $\mathrm{hR} 26$ & 12.739 & & 7.9355 & & & 120 & 26 & 371.8 & & $\underline{4382}$ & 18) \\
\hline $\mathrm{Al}_{3} \mathrm{Mn}_{2}$ & Cubic & $\mathrm{cP} 20$ & 6.424 & & & & & & 20 & 265.1 & & $\underline{4780}$ & 18) \\
\hline $\begin{array}{c}\mathrm{AlMn} \\
\left(\mathrm{Al}_{0.89} \mathrm{Mn}_{1.11}\right) \\
\end{array}$ & Simple Tetragonal & $\mathrm{tP} 4$ & 3.92 & & 3.54 & & & & 4 & 54.4 & 5160 & 5170 & 18) \\
\hline AlMn & Body-Centered Cubic & & 2.98 & & & & & & 2 & 26.5 & & $\underline{5140}$ & 19) \\
\hline $\mathrm{Al}_{9} \mathrm{Mn}_{11}$ & $\begin{array}{c}\text { Close-Packed } \\
\text { Hexagonal }\end{array}$ & hP2 & 2.697 & & 4.356 & & & 120 & 2 & 27.4 & & $\underline{5126}$ & 18) \\
\hline $\mathrm{Al}_{0.89} \mathrm{Mn}_{1.11}$ & Tetragonal & & 2.77 & & 3.54 & & & & 2 & 27.2 & 5160 & 5170 & 21) \\
\hline $\mathrm{Al}_{2} \mathrm{Mn}_{3}$ & Cubic & $\mathrm{cP} 20$ & 6.411 & & & & & & 20 & 263.5 & & 5514 & 20) \\
\hline $\mathrm{AlMn}_{3}$ & Cubic & $\mathrm{cP} 20$ & 6.406 & & & & & & 20 & 262.9 & & $\underline{6057}$ & 18) \\
\hline
\end{tabular}


Table $9 \mathrm{Mn}-\mathrm{Al}$ compact densities before and after reaction.

\begin{tabular}{|c|c|c|c|c|}
\hline \multirow{2}{*}{ Compact Type } & \multicolumn{2}{|c|}{ Apparent Density $\left(\mathrm{g} / \mathrm{cm}^{3}\right)$} & \multirow{2}{*}{$\begin{array}{c}\text { Density Change } \\
(\%)\end{array}$} & \multirow{2}{*}{$\begin{array}{l}\text { Initial Compact Porosity } \\
\text { Before Reaction }(\%)^{15,16)}\end{array}$} \\
\hline & Before Reaction & After Reaction & & \\
\hline 75 mass $\%$ Mn 25 mass $\% \mathrm{Al}$ & 4.53 & 1.66 & -63.43 & 13.2 \\
\hline 60 mass $\% \mathrm{Mn} 40$ mass $\% \mathrm{Al}$ & 3.92 & 1.51 & -61.48 & 9.2 \\
\hline 50 mass $\%$ Mn50 mass $\% \mathrm{Al}$ & 3.66 & 1.75 & -52.09 & 7.1 \\
\hline 40 mass $\%$ Mn60 mass $\% \mathrm{Al}$ & 3.42 & 1.68 & -50.90 & 5.3 \\
\hline
\end{tabular}

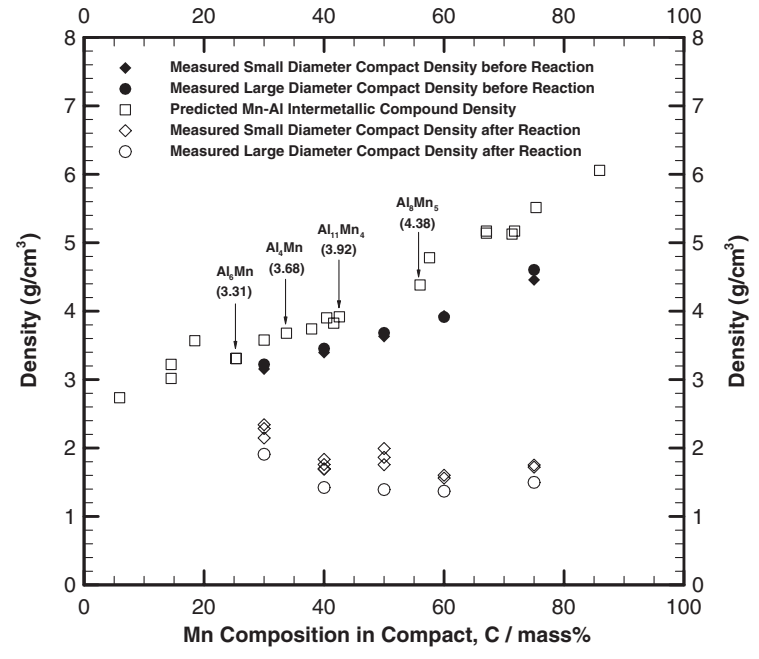

Fig. 11 Comparison between compact measured and predicted densities of different Mn-Al intermetallic compounds.

Figure 11 shows the measured compact densities before and after the intermetallic reaction in a $750^{\circ} \mathrm{C}$ argon protective environment, as well as the estimated densities of the $\mathrm{Mn}-\mathrm{Al}$ intermetallic compounds listed in Table 8. The densities of the $\mathrm{Mn}-\mathrm{Al}$ compacts before and after reaction are listed in Table 9. From Fig. 11, it is obvious that the measured densities of the small and large compacts are decreased dramatically post-reaction compared to prereaction. The calculated densities for the $\mathrm{Mn}-\mathrm{Al}$ intermetallic compounds which exist in the compact after intermetallic reactions are $3.31 \mathrm{~g} / \mathrm{cm}^{3}$ for $\mathrm{Al}_{6} \mathrm{Mn}, 3.68 \mathrm{~g} / \mathrm{cm}^{3}$ for $\mathrm{Al}_{4} \mathrm{Mn}$, $3.92 \mathrm{~g} / \mathrm{cm}^{3}$ for $\mathrm{Al}_{11} \mathrm{Mn}_{4}$, and $4.38 \mathrm{~g} / \mathrm{cm}^{3}$ for $\mathrm{Al}_{8} \mathrm{Mn}_{5}$.

As a point of comparison, reference can be made to the data reported by Perry ${ }^{7)}$ with respect to the measured density of the compact with a composition 75 mass $\%$ Mn 25 mass $\%$ Al. As seen from Table 9, the measured density of this compact composition, as reported in the current study, was $4.53 \mathrm{~g} / \mathrm{cm}^{3}$ prior to the reaction, which is very close to the range of $4.45 \mathrm{~g} / \mathrm{cm}^{3}$ to $4.5 \mathrm{~g} / \mathrm{cm}^{3}$ reported in the Perry study. ${ }^{7)}$ However, the densities measured for the specimen after the reaction were $1.66 \mathrm{~g} / \mathrm{cm}^{3}$ in the current study and $2.24 \mathrm{~g} / \mathrm{cm}^{3}$ reported by Perry. ${ }^{7)}$ The difference between these post-reaction results can potentially be attributed to the following factors:

(a) Size of the compact

(b) Furnace temperature

(c) Heating rate of the specimen

(d) Particle size distribution of metal powders used
It should be pointed out that the above factors would mainly impact the post-reaction results.

Examination of Fig. 11 indicates that the post-reaction densities of all compact compositions are lower than any of the intermetallic densities. By way of illustration, one can compare the compact compositions at the two anchor points. First, in the case of the 75 mass $\%$ Mn 25 mass $\% \mathrm{Al}$ compact, its post-reaction density (as seen in Fig. 11), is below $2 \mathrm{~g} / \mathrm{cm}^{3}$, any intermetallic that may be formed has a density much higher (around $3 \mathrm{~g} / \mathrm{cm}^{3}$ ). By the same token, examining the compact with the lowest Mn content, 30 mass $\% \mathrm{Mn} 70$ mass $\% \mathrm{Al}$, its post-reaction density is again lower than that of any intermetallic that may be formed. The formation of intermetallics is inevitable; however, their densities are consistently higher than the measured postreaction densities of the compacts. It follows, therefore, that the compacts' post-reaction densities are not influenced primarily by the density of the newly formed intermetallics, but rather by the initial porosity of the compact. The compact with the highest initial porosity 75 mass $\% \mathrm{Mn} 25$ mass\% Al (see Table 9, last column) has the lowest post-reaction density (see Fig. 11). As is known, it is inevitable that some residual gas exists in the tiny holes before the reactions. When the $\mathrm{Mn}-\mathrm{Al}$ exothermic reactions are triggered in the compact, the great heat released causes an abrupt expansion of such residual gas, which brings a significant increase in the compact's porosity. From the compact microstructures after the reactions shown in Fig. 12, it can be seen that a large quantity of porosity existed, denoted by the black area in these figures.

In light of the above analysis, it can be concluded that the formation of new intermetallic phases is just a minor reason for the compact swelling phenomenon. The principle reason for the compact swelling seems to be the existence of a large amount of initial porosity inside the compact.

\subsection{Stages of assimilation of Mn-Al compacts into liquid Mg}

The assimilation process is divided into three stages: incubation stage, intermetallic reaction stage, and homogenization stage.

\subsubsection{Incubation stage}

When a $\mathrm{Mn}-\mathrm{Al}$ metal powder compact is first immersed into liquid $\mathrm{Mg}$, the relatively low temperature of the compact leads to the formation of a magnesium shell surrounding the compact. Its thickness is dependent upon the superheat of the $\mathrm{Mg}$ bath and the effective thermal conductivity of the compact. The widely different temperatures of the bath and 

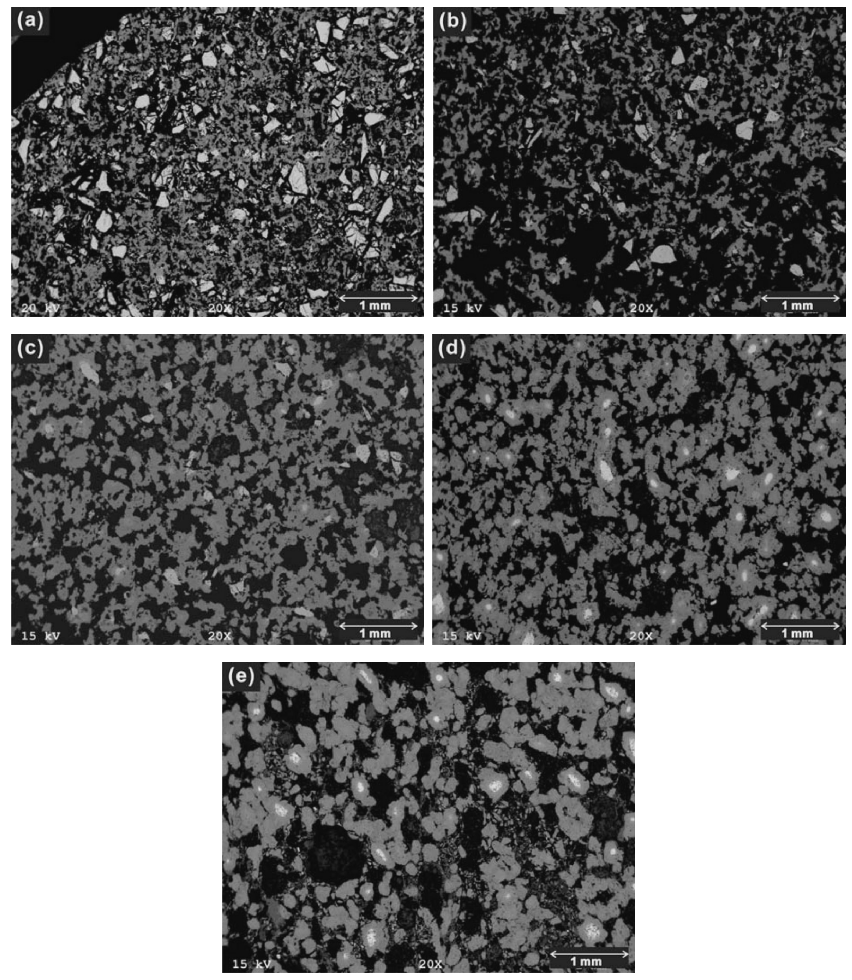

Fig. 12 Backscattered electron images of typical sections of various $\mathrm{Mn}-\mathrm{Al}$ compacts immersed in $750^{\circ} \mathrm{C}$ argon protective atmosphere. (a) 75 mass $\%$ Mn 25 mass $\% \mathrm{Al}$ compact; (b) 60 mass $\% \mathrm{Mn} 40$ mass $\% \mathrm{Al}$ compact; (c) 50 mass $\%$ Mn50 mass $\% \mathrm{Al}$ compact; (d) 40 mass $\%$ Mn60 mass $\% \mathrm{Al}$ compact; (e) 30 mass $\% \mathrm{Mn} 70$ mass $\% \mathrm{Al}$ compact.

the compact produce a strong heat flux into the compact. As the heat passes through the magnesium shell, it gradually melts back until the outside surface of the compact is exposed to the liquid $\mathrm{Mg}$. During this period, the compact accumulates enough heat energy to increase the temperature of the aluminum particles existing in the compact/bath interface to the melting point of $\mathrm{Al}\left(660^{\circ} \mathrm{C}\right)$, and finally melts them.

\subsubsection{Intermetallic reaction stage}

Once the Al particles in the Mn-Al compact have melted, the liquid Al can be transported to the solid Mn sites by a capillary action. Then, a series of exothermic intermetallic reactions between the $\mathrm{Mn}$ particles and liquid $\mathrm{Al}$ in the compact are triggered in a liquid-solid reaction mode to form various $\mathrm{Mn}-\mathrm{Al}$ intermetallic compounds. These intermetallic reactions are exothermic in nature. The result is an abrupt localized temperature increase. The heat released from such intermetallic reactions, combined with the continued inward heat flux from the $\mathrm{Mg}$ bath, is sufficient to increase the temperature of the aluminum particles in the compact interior, triggering again the exothermic reactions there. In such a step-wise manner, the Mn-Al liquid-solid reactions proceed along an inward moving reaction front. In a short period of time, such exothermic reactions are initiated throughout the $\mathrm{Mn}-\mathrm{Al}$ compact. The heat released raises the temperature of the $\mathrm{Mn}-\mathrm{Al}$ compact above the $\mathrm{Mg}$ bath temperature. The intermetallic reaction leads to the formation of several layers of intermetallic compounds around the Mn particles. This series of $\mathrm{Mn}-\mathrm{Al}$ phases includes all the phases that exist in the binary Mn-Al phase with the compositions deviating from their equilibrium counterparts. The encased
Mn particles are separated from each other by the intermetallic compounds. Once the exothermic reactions take place, the $\mathrm{Mn}-\mathrm{Al}$ compact volume increases. This makes the compact structure loose and porous. Despite the sponge-like structure, the compact maintains its rigidity and integrity. Such a porous structure promotes the transport of liquid $\mathrm{Mg}$ from the bath to the reaction sites.

\subsubsection{Homogenization stage}

The reaction heat released from the $\mathrm{Mn}-\mathrm{Al}$ exothermic reactions melts part of the $\mathrm{Mn}-\mathrm{Al}$ reaction products. With the flow of liquid $\mathrm{Mg}$ in the $\mathrm{Mn}-\mathrm{Al}$ compact, which has a loose and porous structure, the liquid solution of $\mathrm{Mn}$ in $\mathrm{Al}$ is brought to the entire $\mathrm{Mg}$ bath. The proper mixing of the $\mathrm{Mg}$ bath significantly accelerates the assimilation process.

\section{Conclusions}

The assimilation mechanism of $\mathrm{Mn}-\mathrm{Al}$ compacts in liquid $\mathrm{Mg}$ has been extensively examined. Two critical steps are involved in the assimilation process: melting of some $\mathrm{Mn}-\mathrm{Al}$ reaction products and mass transfer (i.e. dissolution) of the high $\mathrm{Mn}$ content from the reaction sites to the Mg bath. Three assimilation stages of the $\mathrm{Mn}-\mathrm{Al}$ powder compacts into liquid $\mathrm{Mg}$ have been proposed: the incubation stage, intermetallic reaction stage, and homogenization stage. In tandem with the intermetallic reaction stage, compact swelling was observed. Scientific thought up to now had postulated that compact swelling was the result of the formation of intermetallic reaction products. The current study, however, has thrown new light into this view. The formation of intermetallic phases plays but a minor role in compact swelling. A far more compelling reason for compact swelling is the existence of initial porosity in the compact-and this porosity increases during the intermetallic reaction stage.

\section{Acknowledgments}

The authors would like to acknowledge the financial contribution of the Natural Sciences and Engineering Research Council through a Strategic Grant.

The authors are also indebted to Mr. Timothy J. Kosto of Milward Alloys Inc, in Lockport NY, USA. We are grateful for his invaluable insights as to how the cylindrical specimens had to be manufactured, as well as for the very fruitful discussions with him.

\section{REFERENCES}

1) S. A. Argyropoulos: Trans. Iron and Steel Society of the AIME, (Iron and Steelmaker, May 1990) pp. 77-86.

2) S. A. Argyropoulos and M. Pekguleryuz: CIM Bull. June (2002) 83-86.

3) C. M. Brown, N. J. Pappas and H. J. Brown: US Patent, No. 3592637 , July 13, (1971).

4) Y. E. Lee and D. LeMasters: Light Metals 2001, Ed. by J. L. Anjier, (The Minerals, Metals \& Materials Society, 2001) pp. 985-990.

5) Y. E. Lee and S. L. Houser: Light Metals 2000, Ed. by R. D. Peterson, (The Minerals, Metals \& Materials Society, 2000) pp. 711-717.

6) G. Borge and P. S. Cooper: Light Metals 2002, Ed. by Wolfgang Schneider, (The Minerals, Metals \& Materials Society, 2002) pp. 803809.

7) W. H. Perry: Light Metals 1994, Ed. by U. Mannweiler, (The Minerals, Metals \& Materials Society, 1994) pp. 841-848. 
8) P. Fisher, P. S. Cooper and S. R. Thistlethwaite: Light Metals 1994, Ed. by U. Mannweiler, (The Minerals, Metals \& Materials Society, 1994) pp. 1027-1032.

9) G. T. Campbell and R. E. Bridges: Light Metals 1994, Ed. by U. Mannweiler, (The Minerals, Metals \& Materials Society, 1994) pp. 1093-1097.

10) A. Shafyei and R. I. L. Guthrie: Light Metals 1995, Ed. by J. Evans, (The Minerals, Metals \& Materials Society, 1995) pp. 831-839.

11) Y. E. Lee and D. LeMasters: Light Metals 2002, Ed. by Wolfgang Schneider, (The Minerals, Metals \& Materials Society, 2002) pp. 811816.

12) K. Sun and S. A. Argyropoulos: Can. Metall. Q. 45 (2006) 223-232.

13) K. Sun, S. A. Argyropoulos and T. Kosto: Light Metals and Metal Matrix Composites, 43th Annual Conference of Metallurgists of CIM, (Hamilton, Ontario, Canada, 2004) pp. 345-359.

14) R. Molaei, M. R. Aboutalebi and M. Soltanieh: Can. Metall. Q. 45 (2006) 373-378.

15) Z. Li and S. A. Argyropoulos: Can. Metall. Quarterly 48 (2009) 399_
418.

16) Z. Li: Ph.D. Thesis, Department of Materials Science and Engineering, University of Toronto, (2008).

17) K. Sun, S. Argyropoulos and T. Kosto: Magn. Technol. 2005, (TMS 2005) pp. 127-132.

18) P. Villars and L. D. Calvert: Pearson's Handbook of Crystallographic Data for Intermetallic Phases, (The Materials Information Society, Materials Park, OH 44073, 1991).

19) M. Hansen and K. Anderko: Constitution of Binary Alloys, (McGrawHill Book Company, 1958).

20) International Center for Diffraction Data (ICDD) Powder Diffraction File database-1998, International Centre for Diffraction Data, 12 Campus Boulevard, Newtown Square, PA 19073-3273 U.S.A.

21) W. B. Pearson: A Handbook of Lattices Spacings and Structures of Metals and Alloys-2, (Oxford Pergamon Press, 1967).

22) W. D. Callister, Jr.: Materials Science and Engineering-An Introduction, 5th Edition, (John Wiley \& Sons, Inc., 2000) p. 37. 